\title{
Analisis Rasio Keuangan dan Laporan Corporate Social Responsibility Perusahaan Go Public di Indonesia
}

Yuana Mandagie ${ }^{1}$, Rafrini Amyulianthy ${ }^{2}$, Shanti Lysandra ${ }^{3}$, Ari Pratiwi ${ }^{4}$

1.2.3.4 Universitas Pancasila, Jl. Srengseng Sawah, Jagakarsa, Jakarta Selatan, 12640

\section{INFO ARTIKEL}

JEL Classsification:

M14

Q56

Keywords:

profitability, company

size, leverage,

corporate social

responsibility report

\section{ABSTRACT}

Many factors that influence Corporate Social Responsibility (CSR) disclosure from a company. Therefore, the purpose of this research is to know about the influence of profitability ratios, company size ratios, and leverage ratios to CSR reports on mining companies and manufacturing companies of basic and chemical industry sectors listed in Indonesia Stock Exchange for the 2016 period. This research is a quantitative research that uses 56 companies listed in BEI in 2016 as purposively selected samples. The results of the study found that financial ratios of profitability proxied with Net Profit Margin (NPM) and leverage proxied on Debt to Equity Ratio (DER) partially did not affect the disclosure of CSR. While company size has effect on CSR disclosure.

\begin{abstract}
ABSTRAK
Banyak faktor yang memengaruhi pengungkapan Corporate Social Responsibility (CSR) dari suatu perusahaan. Oleh karena itu, tujuan penelitian tentang analisis rasio keuangan dan laporan CSR perusahaan go public di Indonesia adalah untuk mengetahui tentang pengaruh rasio profitabilitas, rasio ukuran perusahaan, dan rasio leverageterhadap laporan CSR pada perusahaan pertambangan dan perusahaan manufaktur sektor industri dasar dan kimia yang terdaftar di Bursa Efek Indonesia periode 2016. Penelitian ini merupakan penelitian kuantitatif yang menggunakan 56 perusahaan yang terdaftar di BEI pada tahun2016 sebagai sampel yang terpilih secara purposive.Hasil penelitian ditemukan bahwa rasio keuangan profitabilitas yang diproksikan dengan Net Profit Margin (NPM)dan leverage yang diproksikan pada Debt to Equity Ratio (DER) secara parsial tidak berpengaruh terhadap pengungkapan CSR. Sedangkan ukuran perusahaan berpengaruh terhadap pengungkapan CSR.
\end{abstract}

\section{Pendahuluan}

Keberhasilan suatu perusahaan bukan hanya dipengaruhi oleh faktor internal melainkan juga dipengaruhi oleh faktor eksternal antara lain masyarakat dan lingkungan atau komunitas disekitar perusahaan (Rahman, 2009), terutama perusahaan pengolah atau industri. Karena industri dalam perusahaan mengambil andil besar dalam kerusakan lingkungan. Untuk mengurangi dampak kerusakan lingkungan masing-masing perusahaan wajib melakukan corporate social responsibility (CSR). Pengungkapan kegiatan CSR berperan dalam memperoleh keunggulan

*Email Korespondensi: 'yuanamandagie0@univpancasila.ac.id 
kompetitif daripada perusahaan-perusahaan lain, memenuhi kontrak pinjaman, memenuhi kebutuhan ekspetasi masyarakat, untuk menarik investor bahkan sebagai legitimasi tindakan perusahaan (Chintya dan Agus, 2013). Salah satu kunci untuk meningkatkan CSR juga tidak terlepas dari kemampuan manajemen untuk mengelola kinerja keuangan yang fundamental, seperti profitabilitas, ukuran perusahaan dan leverage.

Anggraini (2006) mengungkapkan bahwa rasio profitabilitas menunjukan keberhasilan perusahaan dalam menghasilkan keuntungan. Perusahaan yang memiliki kondisi keuangan yang kuat, akan mendapatkan tekanan yang lebih dari pihak eksternal perusahaan untuk lebih mengungkapkan pertanggungjawaban sosialnya secara luas. Menurut Sembiring (2005), ukuran perusahaan dapat dilihat dari seberapa besar jumlah aset yang dimiliki perusahaan baik current maupun non current asset. Sedangkan financial leverage penting untuk menilai kemampuan perusahaan untuk melunasi hutang-hutangnya. Perusahaan yang mempunyai proporsi hutang yang lebih banyak dalam struktur permodalannya akan mempunyai biaya keagenan yang lebih besar. Oleh karena itu, perusahaan yang memiliki leverage tinggi mempunyai kewajiban yang lebih untuk memenuhi kebutuhan informasi krediturnya (Sari, 2016).

Tetapi beberapa penelitian terdahulu ditemukan bahwa adanya inkonsisten hubungan antara variabel profitabilitas, ukuran perusahaan, leverage, dan CSR, antara lain hasil penelitian Karina (2013), Mulyadi dan Anwar (2012) menyatakan bahwa profitabilitas berpengaruh terhadap pengungkapan CSR. Hasil penelitian Fauziyah dan Husaini (2017) menunjukkan DER berpengaruh signifikan terhadap pengungkapan CSR pada perusahaan sektor pertambangan. Namun, terjadi hasil yang berlawanan pada penelitian Donovan dan Gibson (2000) yang menyatakan bahwa profitabilitas tidak berpengaruh terhadap pengungkapan tanggung jawab sosial perusahaan. Hasil penelitian Anggraini (2006), Agusti dan Indriani (2011) menunjukan bahwa ukuran perusahaan tidak berpengaruh terhadap pengungkapan CSR. Sementara itu hasil penelitian Dewi dan Priyadi (2013), Fahrizqi (2010), serta Nur dan Priantinah (2012) menunjukan bahwa leverage tidak berpengaruh terhadap pengungkapan CSR.

Berdasarkan hal tersebut, maka diperlukan penelitian tentang rasio keuangan dan laporan CSR perusahaan go public di Indonesia dengan tujuan untuk mengetahui tentang pengaruh rasio profitabilitas, rasio ukuran perusahaan, dan rasio leverage secara parsial dan simultan terhadap laporan CSR.

\section{Telaah Teori dan Pengembangan Hipotesis}

Berdasarkan teori legitimasi (legitimacy theory), legitimasi merupakan persepsi tentang tindakan yang dilakukan oleh suatu entitas sesuai dengan tindakan yang diinginkan, pantas ataupun sesuai dengan sistem norma, nilai, kepercayaan dan definisi yang dikembangkan secara sosial (Kirana, 2009). Legitimasi merupakan sistem pengelolaan perusahaan yang berorientasi pada keberpihakan terhadap masyarakat (society), pemerintah individu dan kelompok masyarakat (Ahmad dan Sulaiman, 2004). Fokus dari teori legitimasi adalah hubungan dua arah antara perusahaan dan masyarakat. Teori legitimasi mengakui bahwa aktivitas perusahaan dibatasi oleh kontrak sosial. Di dalam kontrak sosial tersebut disebutkan bahwa perusahaan akan melaporkan kegiatan sosialnya agar memperoleh pengakuan dan diterima oleh masyarakat. Hal tersebut dapat menjamin kelangsungan hidup perusahaan (Kristi, 2013).

Menurut Jensen dan Meckling (1976) teori keagenan adalah sebuah kontrak antara manajemen (agen) dengan pemilik (prinsipal). Perencanaan kontrak yang tepat bertujuan untuk menyelaraskan kepentingan manajer dan pemilik dalam hal konflik dan kepentingan. Hal ini merupakan inti dari teori keagenan. Inti 
hubungan kontraktual berdasarkan teori agensi adalah adanya pemisahan tugas dan fungsi antara kepemilikan investor dan pengendalian manajemen. Namun, pemisahan tersebut sering menimbulkan konflik keagenan antara principles dan agent.

Berdasarkan teori sinyal (signal theory), isyarat atau signal merupakan suatu tindakan yang diambil manajemen perusahaan yang memberi petunjuk bagi investor tentang bagaimana manajemen memandang prospek perusahaan (Moniaga, 2013). Teori sinyal menjelaskan mengapa perusahaan mempunyai dorongan untuk memberikan informasi laporan keuangan pihak eksternal. Kurangnya informasi bagi pihak luar mengenai perusahaan, menyebabkan pihak luar menjadi lebih melindungi diri dengan memberikan harga yang rendah untuk perusahaan. Perusahaan dapat meningkatkan nilai perusahaan dengan mengurangi informasi asimetri antara lain dengan memberikan sinyal pada pihak luar berupa informasi keuangan yang dapat dipercaya akan mengurangi ketidakpastian mengenai prospek perusahaan yang akan datang, yang dimuat dalam laporan tahunan perusahaan.

Menurut Lanis dan Richardson (2012) mengungkapkan bahwa tanggung jawab sosial merupakan salah satu kunci utama kesuksesan dalam keberlangsungan hidup dari perusahaan. Menurut Djajadiningrat dan Melia (2004), tanggung jawab sosial perusahaan merupakan bentuk kepedulian suatu usaha terhadap lingkungan, baik lingkungan di dalam kegiatan usaha maupun diluar kegiatan usaha, misalnya keselamatan para pekerja, penanganan limbah yang dihasilkan sehingga tidak mengganggu masyarakat sekitar. Di Indonesia, CSR merupakan serangkaian kegiatan pameran, seminar, diskusi, social event yang berkaitan dengan berbagai upaya tanggung jawab sosial korporat kepada masyarakat dan lingkungan yang bertujuan sebagai ajang penyebarluasan informasi mengenai prestasi dan kinerja korporasi dalam program tanggung jawab sosial perusahaan dan pemberdayaan masyarakat.
Widyatmoko (2011) mendefinisikan bahwa akuntansi pertanggungjawaban sosial merupakan suatu proses pengkomunikasikan dampak sosial dan lingkungan dari kegiatan ekonomi organisasi terhadap kelompok khusus yang berkepentingan dan masyarakat secara keseluruhan. Pengungkapan CSR merupakan bagian dari akuntansi pertanggungjawaban sosial kepada stakeholder. Perusahaan yang telah melaksanakan CSR dapat mengungkapkan pelaksanaan CSR tersebut baik terintegrasi langsung dalam laporan tahunan maupun laporan terpisah yang sering disebut dengan sustainability report (Annisa dan Nazar, 2015). Hasil penelitian dari berbagai negara membuktikan bahwa laporan tahunan (annual report) merupakan media yang tepat untuk menyampaikan tanggung jawab sosial perusahaan. Pengungkapan CSR dalam laporan tahunan atau sustainability report merupakan laporan aktivitas tanggung jawab sosial yang telah dilakukan perusahaan baik berkaitan dengan perhatian masalah dampak sosial maupun lingkungan. Laporan tersebut menjadi bagian yang tak terpisahkan dengan laporan tahunan yang dipertanggungjawabkan Direksi disidang Rapat Umum Pemegang Saham (RUPS). Laporan ini berisi laporan program-program sosial dan lingkungan perseroan yang telah dilaksanakan selama tahun buku terakhir (Hadi, 2011). Corporate Social Responsibility Disclosure (CSRD) digambarkan sebagai ketersediaan informasi keuangan dan non keuangan yang meliputi manfaat dan biaya sosial berkaitan dengan interaksi organisasi dengan lingkungan fisik dan sosialnya.

Pengungkapan CSR dapat diukur menggunakan Global Reporting Initiative (GRI). GRI merupakan sebuah jaringan berbasis organisasi yang telah memelopori perkembangan dunia, paling banyak menggunakan kerangka laporan berkelanjutan dan berkomitmen untuk terus menerus melakukan perbaikan dan penerapan diseluruh dunia (www.globalreporting.org). Dalam GRI Index terdiri dari tiga indikator pengungkapan 
tanggung jawab sosial yang meliputi : indikator ekonomi, kinerja lingkungan dan kinerja sosial. Pengungkapan CSR dengan indikator GRI dapat dihitung dengan cara menghitung jumlah pengungkapan CSR perusahaan dibagi dengan jumlah item untuk perusahaan.

Rasio keuangan antara lain profitabilitas yang merupakan rasio untuk menilai kemampuan perusahaan dalam mencari keuntungan. Profitabilitas yang tinggi akan menciptakan nilai positif bagi investor dan mempunyai peran penting dalam mempertahankan kelangsungan perusahaan jangka panjang. Sehingga, semakin tinggi tingkat profitabilitas perusahaan, maka semakin besar tingkat pengungkapan sosialnya. Beberapa jenis rasio profitabilitas menurut Gitman (2012): Gross profit margin, Operating profit margin dan Net profit margin (NPM). Semakin tinggi rasio NPM, maka kinerja perusahaan akan semakin produktif, sehingga akan meningkatkan kepercayaan investor untuk menanamkan modalnya pada perusahaan. Perusahaan yang memiliki rasio NPM relatif besar, cenderung memiliki kemampuan untuk bertahan dalam kondisi sesulit apapun. NPM dapat dihitung dengan nilai presentasi laba bersih setelah pajak dibagi nilai total penjualan dari perusahaan.

Rasio keuangan lainnya adalah ukuran perusahaan berupa skala yang digunakan dalam menentukan besar kecilnya suatu perusahaan. Ukuran suatu perusahaan dapat memengaruhi luas pengungkapan informasi dalam laporan keuangan. Perusahaan yang berukuran lebih besar merupakan emiten yang banyak disoroti dan cenderung memiliki keinginan masyarakat akan informasi yang lebih tinggi dibandingkan dengan perusahaan yang berukuran kecil. Hal ini berarti bahwa perusahaan besar akan mengungkapkan informasi lebih banyak daripada perusahaan kecil, karena perusahaan besar akan menghadapi risiko politis yang lebih besar dibandingkan perusahaan kecil. Secara teoritis perusahaan besar tidak akan lepas dari tekanan politis, yaitu tekanan untuk melakukan pertanggugjawaban sosial. Terkait dengan teori agensi menyatakan bahwa perusahaan besar memiliki biaya keagenan yang lebih besar daripada perusahaan kecil (Widyatmoko, 2011). Menurut Setiyadi (2007) ukuran perusahaan yang biasa dipakai untuk menentukan tingkatan perusahaan adalah : tenaga kerja, tingkat penjualan, total hutang, dan total aset. Penelitian ukuran perusahaan dapat menggunakan tolak ukur aset. Linarta (2014) menyatakan bahwa ukuran perusahaan melalui indikator total aset dapat menggunakan nilai perhitungan nilai logaritma total aset. Karena total aset perusahaan bernilai besar maka hal ini dapat disederhanakan dengan mentransformasikan kedalam logaritma natural (Ghozali, 2006), sehingga ukuran perusahaan juga dapat dihitung dengan nilai Ln dari Total Aset. Pengukuran ini dilakukan untuk mengetahui bahwa semakin besar total aset yang dimiliki maka akan semakin besar pula tanggung jawab sosial yang diungkapkan.

Rasio keuangan lainnya adalah Leverage. Fajarini (2012) dan Purnasiwi (2011), menjelaskan bahwa leverage merupakan pengukur besarnya aset yang dibiayai dengan hutang yang digunakan untuk membiayai aset berasal dari pihak luar (kreditor) dengan kemampuan perusahaan yang digambarkan oleh modal. Ketika posisi leverage perusahaan terus mengalami peningkatan, asumsi pasar yang terbentuk akan menyimpulkan bahwa perusahaan sangat memiliki ketergantungan yang tinggi pada hutang, dan risiko untuk melaksanakan kegiatan investasi di dalam perusahaan menjadi relatif tinggi, akan tetapi jika hutang ditingkatkan untuk memacu kinerja dan membiayai berbagai kegiatan yang produktif seperti peningkatan pengungkapan CSR, kebijakan untuk mendorong peningkatan porsi hutang dianggap sangat tepat dilaksanakan.

Menurut Sari (2013) financial leverage merupakan sumber dana atau sumber pembiayaan eksternal yang dimanfaatkan perusahaan untuk di alokasikan pada aset atau untuk melakukan investasi. Financial leverage 
yang tinggi akan membuat keadaan keuangan perusahaan menjadi buruk karena ada resiko kemungkinan gagal bayar hutang (debt default), sehingga perusahaan dengan hutang tinggi lebih memilih melunasi hutang dan beban bunga dari pada melakukan kegiatan CSR. Syamsuddin (2009) menyatakan : "Rasio leverage mengukur berapa besar aset yang dibiayai oleh kreditur. Semakin tinggi debt ratio semakin besar jumlah modal pinjaman yang digunakan di dalam menghasilkan keuntungan bagi perusahaan". Debt to Equity Ratio (DER) dapat dihitung dengan rumus nilai presentasi total utang dibagi total asset yang dimiliki perusahaan (Harahap, 2010).

Berdasarkan teori dan inkonsistensi hasil penelitian sebelumnya, maka hipotesis dalam penelitian ini dapat dirumuskan sebagai berikut: $\mathrm{H}_{1}$ : Profitabilitas berpengaruh secara parsial terhadap CSR

$\mathrm{H}_{2}$ : Ukuran Perusahaan berpengaruh secara parsial terhadap CSR

$\mathrm{H}_{3}$ : Leverage berpengaruh secara parsial terhadap CSR

$\mathrm{H}_{4}$ : Profitabilitas, Ukuran Perusahaan dan Leverage berpengaruh secara simultan terhadap CSR.

\section{Metode Penelitian}

Penelitian ini adalah penelitian kuantitatif, karena data yang diperoleh nantinya berupa angka-angka. Dari angka yang diperoleh akan dianalisis lebih lanjut dalam teknik analisis data cross section. Sumber data dari penelitian ini adalah sumber data sekunder berupa laporan tahunan perusahaan pertambangan dan perusahaan manufaktur sektor industri dasar dan kimia pada tahun 2016 yang terdaftar di BEI.

Teknik pengambilan sampel yang digunakan adalah purposive sampling method.

Kriteria yang digunakan untuk memilih sampel penelitian ini sebagai berikut: Perusahaan pertambangan dan perusahaan manufaktur sektor industri dasar dan kimia yang terdaftar di BEI; perusahaan pertambangan dan perusahaan manufaktur sektor industri dasar dan kimia yang menerbitkan laporan tahunan; perusahaan pertambangan dan perusahaan manufaktur sektor industri dasar dan kimia yang melakukan pengungkapan CSR pada tahun 2016.

Variabel dari penelitian ini terdiri dari tiga variabel independen yaitu : Profitabilitas $\left(\mathrm{X}_{1}\right)$, ukuran perusahaan $\left(\mathrm{X}_{2}\right)$ dan leverage $\left(\mathrm{X}_{3}\right)$ yang digunakan untuk mengetahui apakah terdapat hubungan terhadap variabel dependen yaitu pengungkapan CSR (Y). Data diolah dengan menggunakan program EViews. Data dianalisis secara deskriptif dan pengujian hipotesa. Statistik deskriptif untuk mengetahui karakteristik dari perusahaan yang dijadikan sampel, serta pengujian variabel NPM, ukuran perusahaan dan DER terhadap CSR. Untuk menghasilkan suatu model regresi yang baik, analisis regresi berganda memerlukan pengujian asumsi klasik sebelum melakukan pengujian hipotesis. Apabila terjadi penyimpangan dalam pengujian asumsi klasik, perlu dilakukan perbaikan terlebih dahulu. Pengujian asumsi klasik yang akan dilakukan adalah uji normalitas, uji multikolinearitas, uji heteroskedastisitas dan uji autokorelasi.

Berikut ini adalah hasil pengujian asumsi klasik. Dalam penelitian ini pengujian normalitas menggunakan metode analisis yang dilihat melalui Jarque-Bera test (J-B). Metode ini menggunakan perhitungan skewness dan kurtosis untuk melihat apakah residual berdistribusi normal atau tidak. Jika nilai $\mathrm{p}$ Jarque-bera lebih besar dari taraf signifikansi $(\alpha=5 \%)$ maka residual berdistribusi normal. Sebaliknya jika nilai p Jarque-bera lebih kecil dari taraf signifikansi maka residual berdistribusi tidak normal. Dalam penelitian ini untuk mendeteksi ada tidaknya autokorelasi digunakan uji Durbin Watson, dimana dalam pengambilan keputusan dilihat berapa jumlah sampel yang diteliti dan kemudian melihat angka ketentuannya pada tabel Durbin Watson. Uji multikolinearitas digunakan untuk mengetahui ada atau tidaknya penyimpangan multikolinearitas yaitu adanya hubungan linear 
antar variabel independen dalam model regresi. Prasyarat yang harus dipenuhi dalam model regresi adalah tidak adanya multikolinearitas (Priyatno : 2008). Pengujian multikolinearitas dilakukan terhadap hasil regresi antara variabel independen profitabilitas, company size, dan leverage terhadap pengungkapan CSR. Cara untuk mendeteksi adanya multikolinearitas dilakukan dengan cara meregresikan model analisis dan melakukan uji korelasi antar variabel independen dengan menggunakan variance inflation factor (VIF) dan tolerance value. Apabila nilai tolerance value lebih besar dari 0,1 dan nilai VIF kurang dari 10 maka tidak terdapat multikolinearitas dalam penelitian. Sebaliknya, apabila nilai tolerance kurang dari 0,1 dan nilai VIF lebih besar dari 10 maka terdapat multikolinearitas (Ghozali, 2006). Uji heteroskedastisitas bertujuan untuk menguji apakah dalam model regresi terjadi ketidaksamaan variance dari residual satu pengamatan ke pengamatan yang lain. Jika variance dari residual satu pengamatan ke pengamatan yang lain tetap, maka disebut homoskedastisitas dan jika berbeda disebut heteroskedastisitas. Model regresi yang baik adalah yang homoskedastisitas atau tidak terjadi heteroskedastisitas (Ghozali, 2009). Dalam penelitian ini pengujian heteroskedastisitas menggunakan metode white test. Nilai pObs* $\mathrm{R}^{2}$ white test yang diperoleh kemudian dibandingkan dengan signifikansi $\alpha=5 \%$.

Pengujian hipotesis dalam penelitian ini menggunakan analisis regresi linear berganda yang merupakan studi mengenai ketergantungan variabel dependen dengan satu atau lebih variabel independen (Ghozali, 2011). Analisis ini digunakan untuk memprediksikan nilai dari variabel dependen apabila nilai variabel independen mengalami kenaikan atau penurunan dan untuk mengetahui arah hubungan antara variabel independen dengan variabel dependen apakah masing-masing variabel independen berhubungan positif atau negatif (Priyatno, 2013). Berdasarkan hipotesis yang akan diuji, maka model penelitian sebagai berikut:

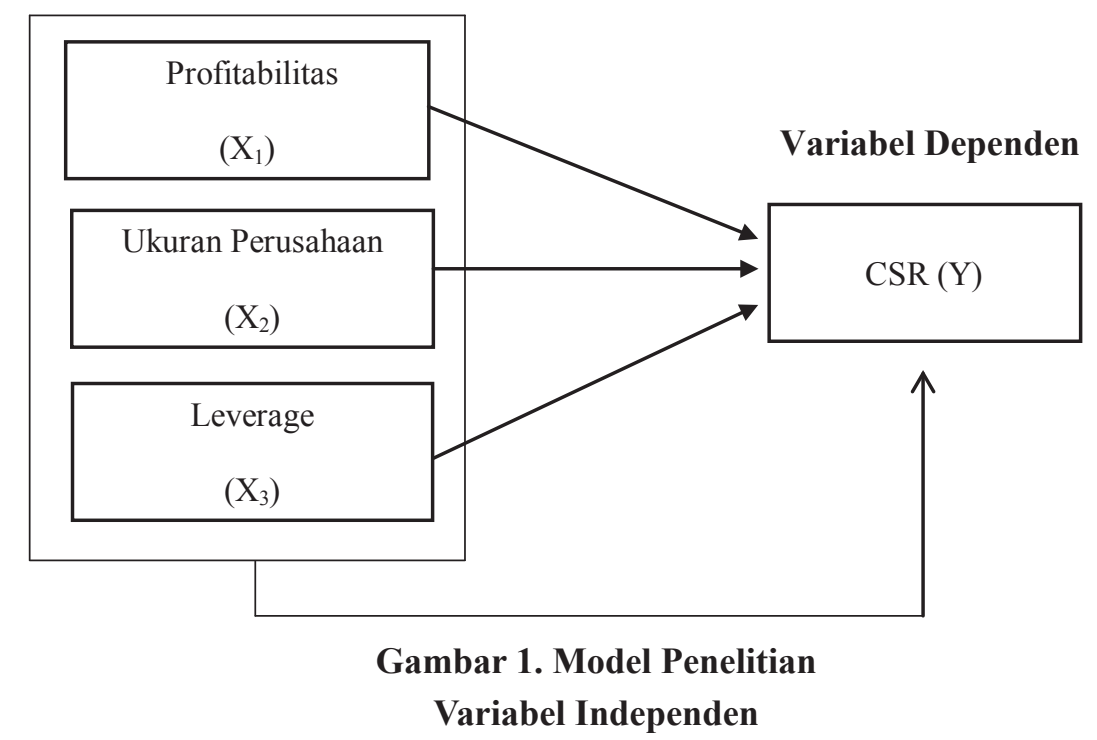

Dalam analisis regresi linier berganda ini, parameter yang digunakan adalah uji t, uji F, dan koefisien determinasi. Sebelum uji regresi linier berganda dilakukan, terlebih dahulu data diuji dengan uji asumsi klasik untuk memastikan model regresi yang digunakan tidak terdapat masalah normalitas, multikolinearitas, heteroskedastisitas, dan autokorelasi. Jika terpenuhi, model analisis tersebut berarti layak digunakan, Ghozali (2013). Model regresi yang digunakan adalah :

$$
\mathrm{Y}=\mathrm{a}+\mathrm{b}_{1} \mathrm{X}_{1}+\mathrm{b}_{2} \mathrm{X}_{2}+\mathrm{b}_{3} \mathrm{X}_{3}+\mathrm{e},
$$


dimana $: \mathrm{Y}=$ Corporate Social Responsibility; $\mathrm{a}=$ Koefisien konstanta; $\mathrm{b}=$ Koefisien regresi dari masing-masing variabel; $\mathrm{X}_{1}=\mathrm{NPM} ; \mathrm{X}_{2}=$ Ukuran Perusahaan; $\mathrm{X}_{3}=$ DER; e $=$ Standard Error.

\section{Hasil Penelitian dan Pembahasan}

Sampel penelitian ada 56 perusahaan. Berdasarkan uji normalitas menunjukan bahwa nilai probabilitas sebesar 0,374868 lebih besar dari nilai signifikansi yang digunakan, yaitu 0,05 atau probabilitas $=0,374868>\alpha=0,05$. Sehingga dapat disimpulkan bahwa data dalam penelitian ini berdistribusi normal.

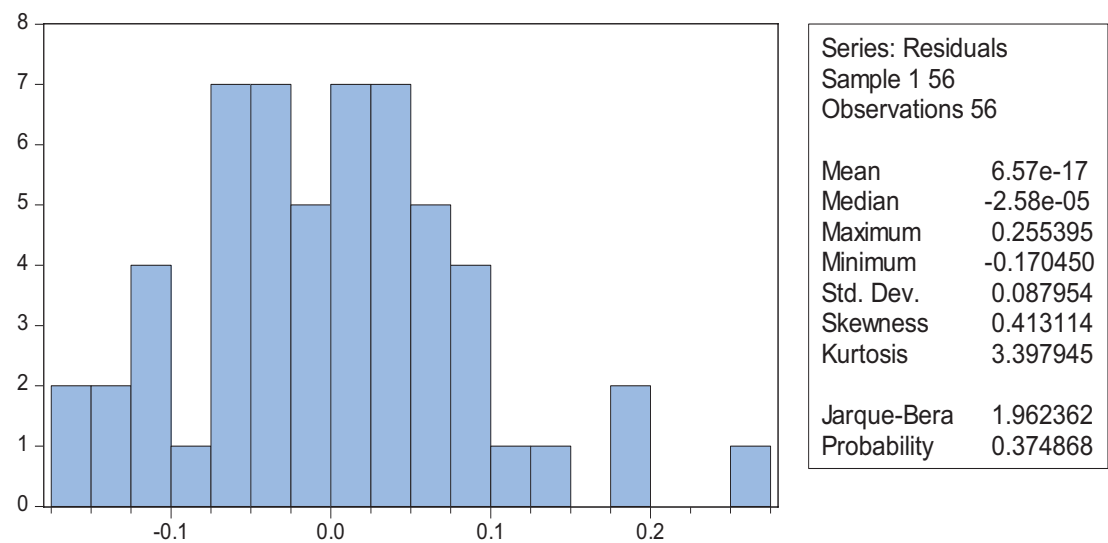

Gambar 2. Uji Normalitas

Sumber: Output Eviews, 2017

Tabel 1. Uji Autokorelasi

\begin{tabular}{lllllll}
\hline Variabel & $\mathrm{N}$ & $4-\mathrm{du}$ & $\mathrm{Du}$ & $\mathrm{DL}$ & Nilai DW & Keputusan \\
\hline CSR & 56 & 2,317 & 1,6830 & 1,4581 & 1,702777 & $\begin{array}{l}\text { Tidak ada autokorelasi, } \\
\text { positif atau negatif }\end{array}$ \\
\hline
\end{tabular}

Sumber: Output Eviews, 2017

Berdasarkan tabel 1, nilai Durbin-Watson sebesar 1,702777 untuk jumlah variabel bebas 3 dan jumlah sampel 56 didapat $d u=1,6830$ dan $\mathrm{dl}=1,4581$. Berdasarkan hasil yang didapat dari tabel durbin-watson diketahui bahwa pengujian tidak ada autokorelasi karena 1,6830 lebih kecil dari 1,702777 lebih kecil dari 2,317 atau du $<$ $\mathrm{dw}<4-\mathrm{du}$.

Tabel 2. Uji Multikolinearitas

\begin{tabular}{llll}
\hline Variabel & Coefficient Variance & Uncentered VIF & Centered VIF \\
\hline $\mathrm{C}$ & 0.016522 & 113.0797 & NA \\
Profitabilitas & 0.001862 & 1.197990 & 1.197957 \\
Ukuran Perusahaan & $7.84 \mathrm{E}-05$ & 114.5859 & 1.196731 \\
Leverage & $1.15 \mathrm{E}-05$ & 1.238583 & 1.041049 \\
\hline
\end{tabular}

Sumber: Output Eviews, 2017 
Berdasarkan tabel 2, menunjukkan bahwa semua nilai VIF variabel profitabilitas, ukuran perusahaan, dan leverage kurang dari 10 , sehingga dapat disimpulkan dalam model regresi ini tidak terjadi gejala multikolinearitas yaitu korelasi antar variabel bebas.

Tabel 3. Uji Heteroskedastisitas

\begin{tabular}{llll}
\hline F-Statistic & 2,529208 & Prob. F (3,52) & 0,0673 \\
\hline Obs*R-squared & 7,130792 & Prob. Chi-Square (3) & 0,0678 \\
Scaled Explained SS & 7,371871 & Prob. Chi-Square (3) & 0,0609 \\
\hline
\end{tabular}

Sumber: Output Eviews, 2017

Dari hasil uji heteroskedastisitas, dapat dilihat bahwa nilai p- Obs*R-squared sebesar $0,0678>5 \%$, sehingga dapat disimpulkan bahwa tidak ditemukan adanya masalah heteroskedastisitas.

Analisis data yang digunakan dalam

penelitian ini adalah analisis regresi linear berganda untuk mengetahui besarnya pengaruh yang ditimbulkan antara pengaruh profitabilitas, ukuran perusahaan dan leverage terhadap pengungkapan CSR perusahaan pertambangan dan perusahaan manufaktur sektor industri dasar dan kimia tahun 2016 :

Tabel 4. Uji F

\begin{tabular}{llll}
\hline Variabel & Coefficient & t-Statistik & Prob \\
\hline C & -0.351429 & -2.734046 & 0.0085 \\
Profitabilitas & 0.071524 & 1.657668 & 0.1034 \\
Ukuran Perusahaan & 0.046566 & 5.259588 & 0.0000 \\
Leverage & -0.005675 & -1.677041 & 0.0995 \\
R-squared & 0.467951 & & \\
Adjusted R-squared & 0.437256 & & \\
F-statistic & 15.24510 & Durbin-Watson stat & 1.702777 \\
Prob (F-statistic) & 0.000000 & & \\
\hline
\end{tabular}

Sumber: Output Eviews, 2017

Berdasarkan tabel 4 , hasil uji $\mathrm{F}$ dengan variabel dependen pengungkapan CSR pada perusahaan pertambangan dan perusahaan manufaktur sektor industri dasar dan kimia yang terdaftar di BEI tahun 2016 dapat dilihat dari nilai $F_{\text {hitung }}$ yaitu sebesar 15,245 dan sig. 0,000 lebih kecil dari 0,05. Sehingga dapat disimpulkan bahwa terdapat pengaruh variabel profitabilitas, ukuran perusahaan dan leverage secara simultan terhadap pengungkapan CSR. Hasil perhitungan untuk nilai $\mathrm{R}$ Square $\left(\mathrm{R}^{2}\right)$ atau angka koefisien determinasi $=0,468$ atau 46,8\%. Artinya kemampuan variabel-variabel independen yang terdiri dari profitabilas, ukuran perusahaan dan leverage dalam menjelaskan variabel dependen yaitu pengungkapan CSR sebesar 46,8\%. Sisanya $(100 \%-46,8 \%=53,2 \%)$ dipengaruhi oleh variabel lain di luar model yang tidak diteliti dalam penelitian ini. Persamaan regresi linear berganda yang dihasilkan adalah :

$\mathrm{Y}=\mathbf{- 0 , 3 5 1}+\mathbf{0 , 0 7 2}$ Profitabilitas $+\mathbf{0 , 0 4 7}$ Ukuran Perusahaan - 0,006 Leverage + $\mathrm{e}$

Konstanta bernilai negatif sebesar $-0,351$, menunjukkan bahwa apabila keseluruhan variabel konstan, maka pengungkapan CSR 
adalahsebesar-0,351; Koefisien $\mathrm{X}_{1}$, sebesar 0,072 yang berarti apabila profitabilitas meningkat sebesar satu satuan maka pengungkapan CSR akan mengalami kenaikan sebesar 0,072 dengan asumsi nilai variabel lain tetap; Koefisien $\mathrm{X}_{2}$, sebesar 0,047 yang berarti apabila ukuran perusahaan meningkat sebesar satu satuan maka pengungkapan CSR akan mengalami kenaikan sebesar 0,047 dengan asumsi nilai variabel lain tetap; Koefisien $\mathrm{X}_{3}$, sebesar -0.006 yang berarti apabila leverage meningkat sebesar satu satuan maka pengungkapan CSR akan mengalami penurunan sebesar 0,006 dengan asumsi nilai variabel lain tetap.

Pengujian hipotesis dalam penelitian ini menggunakan uji $\mathrm{t}$ untuk menunjukan seberapa jauh pengaruh masing-masing variabel independen secara individu dalam menerangkan variasi variabel dependen (Ghozali : 2011). Pengujian ini menggunakan level signifikan $(\alpha)$ 0,05 . Jika nilai signifikansi lebih kecil dari 0,05 maka artinya terdapat pengaruh signifikan antara variabel independen dengan variabel dependen dan sebaliknya. Hasil uji t dapat dilihat sebagai berikut :

Tabel 5. Hasil Uji t

\begin{tabular}{llll}
\hline Variabel & $\mathbf{t}_{\text {hitung }}$ & Sig. & Kesimpulan \\
\hline Profitabilitas & 1,6577 & 0,1034 & Hipotesa ditolak \\
Ukuran Perusahaan & 5,2596 & $0,0000^{*}$ & Hipotesa diterima \\
Leverage & $-1,6770$ & 0,0995 & Hipotesa ditolak \\
\hline
\end{tabular}

Ket : * $=$ Sig 5\%

Berdasarkan tabel 5, Profitabilitas mempunyai nilai signifikansi sebesar 0,1034 , dimana lebih besar dari $\alpha=5 \%$, sehingga dapat dikatakan bahwa variabel profitabilitas tidak berpengaruh terhadap pengungkapan CSR. Artinya besar kecilnya jumlah profitabilitas perusahaan tidak memengaruhi pengungkapan tanggung jawab sosial perusahaan; Ukuran perusahaan mempunyai nilai signifikansi sebesar 0.0000, dimana lebih kecil dari $\alpha=$ $5 \%$, sehingga dapat dikatakan bahwa variabel ukuran perusahaan memiliki pengaruh terhadap pengungkapan CSR. Leverage mempunyai nilai signifikansi sebesar 0.0995, dimana lebih besar dari $\alpha=5 \%$, sehingga dapat dikatakan bahwa variabel leverage tidak berpengaruh terhadap pengungkapan CSR Penelitian ini sejalan dengan penelitian yang dilakukan oleh Purwanto (2011), Putri dan Christiawan (2014) yang menemukan hasil penelitian bahwa tidak adanya pengaruh profitabilitas terhadap pengungkapan tanggung jawab sosial perusahaan. Sedangkan penelitian yang dilakukan oleh Reka Maiyarni (2014) menemukan hasil yang sebaliknya.
Hasil penelitian menunjukan bahwa ukuran perusahaan berpengaruh terhadap pengungkapan CSR, artinya semakin besar ukuran perusahaan maka akan semakin berpengaruh terhadap pengungkapan CSR. Semakin besar aset yang dimiliki oleh perusahaan maka perusahaan tidak lepas dari sorotan masyarakat, publik dan khususya regulator. Perusahaan harus memperhatikan keadaan lingkungan sosial, yaitu dengan melakukan pengungkapan tanggung jawab sosial perusahaan yang lebih meluas agar kepercayaan masyarakat terhadap perusahaan memiliki citra yang baik dimata masyarakat. Hasil penelitian ini sejalan dengan penelitian yang dilakukan oleh Sari (2013) bahwa ukuran perusahaan berpengaruh terhadap pengungkapan tanggung jawab sosial perusahaan. Sedangkan penelitian Oktariani dan Mimba (2014) menemukan hasil penelitian sebaliknya.

Hasilpenelitian menunjukanbahwaleverage yang diproksikan pada DER tidak berpengaruh terhadap pengungkapan CSR, artinya semakin besar tingkat leverage perusahaan maka akan memengaruhi pengungkapan CSR perusahaan. 
Hasil penelitian ini sejalan dengan hasil penelitian Oktariani dan Mimba (2014), Purwaningsih dan Suyanto (2015) yang menjelaskan bahwa adanya pengaruh leverage terhadap pengungkapan CSR.

\section{Kesimpulan, Keterbatasan dan Implikasi Hasil Penelitian}

Penelitian ini bertujuan untuk menguji pengaruh Dari hasil analisis menunjukan bahwa variabel profitabilitas yang diproksikan pada NPM dan variabel leverage yang diproksikan pada DER secara parsial tidak berpengaruh terhadap Corporate Social Responsibility. Sedangkan variabel ukuran perusahaan berpengaruh terhadap CSR.

Bagi perusahaan, informasi yang diperoleh dari penelitian ini dapat digunakan sebagai bahan pertimbangan untuk mengevaluasi, memperbaiki, dan lebih memperhatikan pengungkapan CSR perusahaan bukan hanya karena adanya dorongan peraturan semata. Karena dari hasil penelitian ini ditemukan bahwa untuk meningkatkan pengungkapan CSR maka perusahaan harus memperhatikan variabel yang berpengaruh terhadap CSR yaitu ukuran perusahaan dan leverage. Dengan melakukan pengungkapan CSR, perusahaan berarti ikut serta dalam menjaga lingkungan sehingga akan memperkecil resiko kerusakan alam maupun resiko penolakan masyarakat terhadap kegiatan operasional masyarakat. Bagi Investor, dalam membuat keputusan investasi sebaiknya investor lebih memperhatikan luasnya pengungkapan CSR yang dilakukan oleh perusahaan. Jika ingin berinvestasi di perusahaan yang melakukan pengungkapan CSR dapat mempertimbangkan variabel yang berpengaruh dalam penelitian ini yaitu ukuran perusahaan dan leverage.

Untuk peneliti selanjutnya sebaiknya menggunakan sampel perusahaan yang lebih banyak dan rentang waktu yang lebih lama agar hasil pengujian lebih akurat serta menambah variabel penelitian lainnya yang diduga memiliki pengaruh terhadap pengungkapan CSR seperti variabel likuiditas, activity ratio, corporate governance dan sebagainya.

\section{Daftar Referensi}

Agusti, R., \& Indriani, D. (2011). Pengaruh Leverage, Profitabilitas, Size, Umur Perusahaan dan Ukuran Dewan Komisaris Terhadap Pengungkapan Tanggung Jawab Sosial Perusahaan (Studi pada Perusahaan Pertambangan yang Listing di BEI tahun 2004-2008). PEKBIS (Jurnal Pendidikan Ekonomi Dan Bisnis), 3(01).

Anggraini, F. R. R. (2006). Pengungkapan informasi sosial dan faktor-faktor yang mempengaruhi pengungkapan informasi sosial dalam laporan keuangan tahunan (Studi empiris pada perusahaanperusahaan yang terdaftar Bursa Efek Jakarta). Simposium Nasional Akuntansi, 9 , 23-26.

Annisa, I. N., \& Nazar, M. R. (2015). Pengaruh Struktur Kepemilikan Dengan Variabel Kontrol Profitabilitas, Umur, Dan Ukuran Perusahaan Terhadap Luas Pengungkapan Corporate Social Responsibility (Studi Empiris Perusahaan Manufaktur Di Bei Tahun 2011-2013). eProceedings of Management, 2(1).

Dewi, Sukmawati S dan Maswar P. P. 2013. Pengaruh Karakteristik Perusahaan terhadap Corporate Social Responsibility Disclosure pada Perusahaan Manufaktur yang Terdaftar di BEI. Jurnal Ilmu dan Riset Akuntansi. Volume 2. Nomor 3, Hal 6-16

Djajadiningrat, S. T. Dan Melia F. 2004. Kawasan Industri Berwawasan Lingkungan (EkoIndustrial Park) Fenomena Baru dalam Membangun Industri dan Kawasannya Demi Masa Depan Berkelanjutan.

Donovan, Gary and Gibson, Kathy, (2000). Environmental Disclosure in the Corporate Annual Report: A Longitudinal Australian Study. Paper for Presentation in the 6th Interdisciplinary Environmental 
Association Conference, Montreal, Canada Fahrizqi, A., \& DARSONO, D. (2010). Faktor-

Faktor Yang Mempengaruhi Pengungkapan Corporate Social Responsibility (CSR) Dalam Laporan Tahunan Perusahaan (Studi Empiris Pada Perusahaan Manufaktur Yang Terdaftar Dalam Bursa Efek Indonesia) (Doctoral dissertation, Universitas Diponegoro).

Fajarini, I., \& Susanto, A. (2012). Pengaruh Biaya Politis, Leverage, dan ROE Terhadap Pengungkapan Pertanggung Jawaban Sosial Pada Perusahaan Manufaktur di Bursa Efek Indonesia. In Eco-Entrepreneurship Seminar \& Call Paper.

Fauziyah, H., \& Husaini, A. (2017). Analisis Pengaruh Financial Performance terhadap Pengungkapan Corporate Social Responsibility (Studi pada Sektor Pertambangan yang Terdaftar di Bei Periode Tahun 2013-2015). Jurnal Administrasi Bisnis, 50(3), 145-152.

Ghozali, Imam. 2006. Aplikasi Analisis Multivariate dengan Program SPSS. Semarang : Badan Penerbit Universitas Diponegoro

Ghozali, Imam, 2009. Aplikasi Analisis Multivariate dengan Program SPSS, Edisi keempat. Badan penerbit universitas diponegoro. Semarang

Ghozali, Imam. 2011. Aplikasi Analisis Multivariate dengan Program IBM SPSS 19. Edisi 5. Semarang: Badan Penerbit Universitas Diponegoro.

Ghozali, I., \& Ratmono, D. (2013). Analisis Multivariat dan Ekonometrika, Teori, Konsep dan Aplikasi dengan Eviews 8. Semarang: Badan Penerbit Universitas Diponegoro.

Gitman, Lawrence J, \& Chad J. Zutter. 2012. Principles of Managerial Finance. $13^{\text {th }}$ Edition. Global Edition : Pearson International Edition.

Harahap, Sofyan Safri, 2010, Analisis Kritis Atas Laporan Keuangan, Jakarta : Rajawali
Persada.

Jensen, M. C., \& Meckling, W. H. (1976). Theory of the firm: Managerial behavior, agency costs and ownership structure. Journal of financial economics, 3(4), 305-360.

Karina, L. A. D., \& Yuyetta, E. N. A. (2013). Analisis Faktor-Faktor Yang Mempengaruhi Pengungkapan Csr (Studi Empiris Pada Perusahaan Manufaktur yang Terdaftar di Bursa Efek Indonesia tahun 2011) (Doctoral dissertation, Fakultas Ekonomika dan Bisnis).

Kartadjumena, E., Hadi, D. A., \& Budiana, N. (2011). The relationship of profit and corporate social responsibility disclosure (Survey on manufacture industry in Indonesia).

Kirana, R. Candra. 2009. Studi Perbandingan Pengaturan tentang Corporate Social Responsibility di Beberapa Negara Dalam Upaya Perwujudan Prinsip Good Corporate Governance. Tesis. Surakarta : USM.

Kristi, A. A. (2013). Faktor-Faktor yang Mempengaruhi Pengungkapan Corporate Social Responsibility pada Perusahaan Publik di Indonesia. Jurusan Akuntansi, Fakultas Ekonomi dan Bisnis, Universitas Brawijaya.

Laksmitaningrum, Fadila, C., \& Purwanto, A. (2013). Analisis Pengaruh Karakteristik Perusahaan, Ukuran Dewan Komisaris dan Struktur Kepemilikan Terhadap Pengungkapan CSR (Studi Empiris pada Perusahaan Manufaktur Yang Terdaftar Di Bursa Efek Indonesia Tahun 20092011) (Doctoral dissertation, Fakultas Ekonomika dan Bisnis).

Lanis, R., \& Richardson, G. (2012). Corporate social responsibility and tax aggressiveness: An empirical analysis. Journal of Accounting and Public Policy, 31(1), 86108.

Linarta, J. (2014). Analisis Pengaruh Profitabilitas, Umur Perusahaan, Ukuran Perusahaan, dan Tipe Industri 
terhadap Pengungkapan Corporate Social Responsibility (CSR) pada Perusahaan Manufaktur (Studi Empiris pada Perusahaan yang Terdaftar di BEI Tahun 2009-2013). Penelitian Terpublikasi Jurusan Ekonomi Program Studi Akuntansi. Universitas Katolik Atma Jaya. Jakarta.

Maiyarni, Reka., Susfayetti., Erwati, MIsni. 2014. Pengaruh Profitabilitas, Ukuran Perusahaan, Likuiditas dan Leverage Terhadap Pengungkapan Corporate Social Responsibility (CSR) Pada Perusahaan LQ45 yang Terdaftar Di BursaEfek Indonesia Periode 2009-2012. Jurnal Cakrawala Akuntansi. Vol. 6 No. 1.

Moniaga, Fernandes. 2013. Pengaruh Struktur Modal, Profitabilitas dan Struktur Biaya Terhadap Nilai Perusahaan Industri Keramik, Procelen dan Kaca Periode 20072011. Jurnal EMBA. ISSN 2303-1174. Vol. 1 No 4, Hal. 433-442.

Mulyadi, M. S., \& Anwar, Y. (2012). Impact of corporate social responsibility toward firm value and profitability. The Business Review, Cambridge, 19(2), 316-322.

Nazli Nik Ahmad, N., \& Sulaiman, M. (2004). Environment disclosure in Malaysia annual reports: A legitimacy theory perspective. International Journal of Commerce and Management, 14(1), 44-58.

Nur M., \& Priantinah, D. (2012). Analisis Faktorfaktor Yang Mempengaruhi Pengungkapan Corporate Social Responsibility Di Indonesia. Jurnal Nominal, 1.

Oktariani, N. W., \& Mimba, N. P. S. H. (2014). Pengaruh Karakteristik Perusahaan Dan Tanggung Jawab Lingkungan Pada Pengungkapan Tanggung Jawab Sosial Perusahaan. E-Jurnal Akuntansi, 6(3), 402418.

Purnasiwi, J. (2011). Analisis Pengaruh Size, Profitabilitas dan Leverage Terhadap Pengungkapan CSR pada Perusahaan yang Terdaftar di Bursa Efek Indonesia (Doctoral dissertation, Universitas Diponegoro).
Purwaningsih, R. P. dan Suyanto. 2015. Pengaruh Profitabilitas dan Leverage Terhadap Pengungkapan Corporate Social Responsibility (CSR) Perusahaan (Studi Kasus Pada Perusahaan Manufaktur Yang Tercatat Di Bursa Efek Indonesia Tahun 2011-2013). Syariah Paper Accounting FEB UMS. 133-140.

Purwanto, A. (2011). Pengaruh Tipe Industri, Ukuran Perusahaan, Profitabilitas, Terhadap Corporate Social Responsibility. Jurnal Akuntansi dan Auditing, 8(1), 12-29.

Putri, Rafika Anggraini dan Yulius Jogi Christiawan. 2014. Pengaruh Profatibilitas, Likuiditas, dan Leverage terhadap Pengungkapan Corporate Social Responsibility (Studi pada Perusahaan-Perusahaan yang Mendapat Penghargaan ISRA dan Listed (Go-Public) di Bursa Efek Indonesia (Bei) 2010-2012). Jurnal Business Accounting Review. Vol. 2, No. 1.

Rahman, R., \& Deti. (2009). Corporate social responsibility: Antara teori dan kenyataan. Medpress.

Sari, M.P.Y.(2013). Pengaruh Kinerja Keuangan, Ukuran Perusahaan dan Corporate Governance terhadap Pengungkapan Sustainability report. Unpublished undergraduate thesis, Universitas Diponegoro, Semarang.

Sari, R. P. (2013). Pengaruh Financial Leverage Dan Size Perusahaan Terhadap Pengungkapan Tanggung Jawab Sosial Perusahaan (Studi Empiris Pada Perusahaan Manufaktur yang Terdaftar di BEI). Jurnal Akuntansi, 1(1).

Sembiring, E. R. (2005). Karakteristik Perusahaan dan Pengungkapan Tanggung jawab Sosial Pada Perusahaan yang Tercatat di Bursa Efek Jakarta. Simposium Nasional Akuntansi, 7, 15-16.

Setiyadi. 2007. "Pengaruh Company Size, Profitability, dan Institutional Ownership terhadap CSR Disclosure”. Jurnal Ekonomi. Universitas Padjajaran Bandung. 
Jurnal Riset Akuntansi dan Perpajakan JRAP Vol. 5, No. 2, Desember 2018, hal 131-143 ISSN 2339 - 1545

Syamsuddin, Lukman. 2009. Manajemen Keuangan Perusahaan. Jakarta: PT Raja Grafindo Persada.

Widyatmoko, R., \& Ardiyanto, M. D. (2011). Pengaruh Karakteristik Perusahaan Terhadap Pengungkapan Laporan Tanggung jawab Sosial (Studi Empiris pada Perusahaan Pertambangan yang terdaftar dalam Bursa Efek Indonesia)(Doctoral dissertation, Universitas Diponegoro).

www.globalreporting.org, diakses pada 30

Oktober 2017.

www.idx.co.id, diakses pada 2 Oktober 2017. 